\title{
4/3/2: Türkçenin Yabancı Dil Olarak Öğretiminde Konuşmada Akıcılığı Geliştirmek için Etkili Bir Teknik
}

\author{
Kadir Vefa Tezel * \\ * Dr. Öğr. Üyesi, Bolu Abant İzzet Baysal Üniversitesi, Bolu/Türkiye \\ E-Posta: vefa2000@gmail.com \\ ORCID: $\quad \underline{0000-0002-2636-1221}$
}

Öz

Yabancı dil öğrenen insanların karşılaştı̆̆ı en yaygın sorunlardan biri, akıllarındaki fikirleri ifade ederken konuşmalarındaki yetersizlikler nedeniyle yaşadıkları tereddütler ve kullanmak zorunda kaldıkları duraksamalar ve dolgu seslerdir. Bu sorunlar öğrencilerin konuşmalarında sıkıntılar yaratır ve hemen göze çarpar. Öğrencilerin yaşadı̆̆g bu sorunlarm nedeni akıcılık konusunda eğitim almamalar ve uygulama yapmamalarıdır. Akıcılık, eğitimi verilmesi gereken bir alandır ve bu makalede detaylı olarak tanttılan 4/3/2 tekniği akıcılık eğitimi ve uygulamaları sırasında güvenle kullanılacak denenmiş bir tekniktir. Bu teknikte öğrenciler aşina oldukları bir konu hakkında 3 farklı dinleyiciye 4, 3 ve 2 dakika boyunca konuşur ve aynı mesajı aktarılar. Konuşmaların 4 ve 2 dakikalık kısımları kaydedilip, metinleştirilir ve öğrencilerin bir dakikada kullandıkları kelime sayısı, yaptıkları duraksama sayıları ve kullandıkları karmaşık cümlelerin sayısı gibi ölçütler kullanılarak akıcıllklarındaki gelişmeler değerlendirilir. Bu tekniğin sınıf içi uygulamalarında içerik önemli olduğundan, kullanılacak konular da makalede sunulmuştur. Öncelikle orta ve ileri seviyeler için geliştirilen bu teknik alt seviyeler veya ders saati sürelerinde yetersizliklerin olduğu durumlarda da adapte edilerek bu makalede önerilen konuları kullanmak yoluyla uygulanabilir.

Anahtar Kelimeler: Türkçenin yabancı dil olarak öğretimi, konuşma becerisi, akıcılık, 4/3/2 tekniği. 


\title{
4/3/2: An Effective Technique to Develop Fluency in Speaking in Teaching Turkish as a Foreign Language
}

\begin{abstract}
One of the most common problems people learning a foreign language face is the hesitations they experience and the stops and pause fillers they have to use while expressing the ideas they have in their minds. These problems cause difficulties in learners' speech and immediately become noticeable. The reason for these problems is that learners do not receive training and practice in fluency. Fluency is an area in which training needs to be given, and the 4/3/2 technique, introduced in detail in this article, is a tested and reliable technique to be used during fluency training and practice. In this technique, learners talk about a familiar topic to 3 different listeners for 4, 3, and 2 minutes and relay the same message. The 4 and 2-minute parts of their speeches are recorded and transcribed, and the improvements in their fluency are evaluated by using criteria such as the number of words they use per minute, the number of pauses they make, and the number of complex sentences they use in their speeches. Since content is important in the classroom applications of the technique, the topics to be used are also presented in the article. Primarily developed for the intermediate and advanced levels, this technique can be also adapted to be used at lower levels or in classes in which the number of instruction hours is insufficient.
\end{abstract}

Keywords: Teaching Turkish as a foreign language, speaking skill, fluency, 4/3/2 technique. 


\section{Giriş}

Türkiye'nin sanayi, ticaret ve uluslararası politika alanlarında son yıllarda giderek önem kazanması, başka ülke vatandaşlarında da karşılık bulmuş ve Türkçe öğrenmek hem komşu hem de uzak coğrafyadaki ülke insanları için giderek önem kazanmaya başlamıştır. Türkçe bugün Hindistan'da bile üniversite öğrencilerinin bir meslek sahibi olmak için öğrenmeyi tercih ettikleri bir yabancı dil haline gelmiştir (Maden ve İşcan, 2011). Türk üniversitelerinin yurtdışı tanıtım çalışmaları da Türkçeyi öğrenme ve Türkiye'de eğitim alma isteğini arttırmıştır. Yunus Emre Enstitüsü ve Yurtdışı Türkler ve Akraba Topluluklar Başkanlığ gibi kurumların çalışmaları ile de Türkçenin yabancı dil olarak öğretilmesinde önemli adımlar atılmıştır.

İnsanların Türkçe öğrenme ihtiyaçlarını karşılamak, nitelikli Türkçe öğretim programları, araçları ve ortamları sunmakla daha kolay hale getirilebilir. Özellikle, dinleme ve konuşmaya dayalı sözlü iletişim becerilerinin öğretiminde Türkçeyi yabancı dil olarak öğrenenlerin kendi gelişimlerinin bilinçli olarak farkına varacakları öğretim programları ve etkinlikler, onları motive edecek ve diğer dil becerilerinin gelişmesine de olumlu katkılar sağlayacaktır. Dolayısıyla, artık bir dünya dili haline gelen Türkçenin yabancı dil olarak öğretiminde, öğrencilerin her düzeyde dört dil becerisini rahatça kullanabilmelerine olanak sağlayan etkili öğretim yöntem ve tekniklere ihtiyaç vardır. Bu tekniklerden biri de akıcı konuşmayı hızlandıran 4/3/2 tekniğidir.

\section{Akıcı Konuşma}

Türkçeyi yabancı dil olarak öğrenenlerin en sık yaşadığı zorluklardan biri, duygu ve düşüncelerini ifade etmede karşılaştıkları tutukluktur. Bu kişiler kendi ana dillerinde her türlü duygu ve düşünceyi rahatça ifade edebilecek dil yeterliliğine sahip olmalarına rağmen, aynı şeyi Türkçeyi kullanarak yapmaya kalktıkları zaman, isabetli kelime ve dilbilgisi yapılarını seçme, düşüncelerini ifadelere dönüştürme ve dinleyiciye aktarmada zorluklar yaşarlar. Bu zorluklar kendilerini öğrenciler Türkçe konuşma yaptıkları zaman ortaya çıkan tutukluklar olarak gösterir. 
Konuşma becerisindeki bu tutukluklar, telaffuz ve tonlamada hatalarının da eklenmesiyle, konuşmada kendisini daha çok belli eder.

Arzu edilmediği halde son derece sik rastlanan bu durum, konuşmada akıcılık kazanamamaktan kaynaklanır. Konuşmada akıcılık, birçok dil öğretim programında temel bir unsur olarak değerlendirilmezken, Nation ve Newton (2009) akıcılığı, anlam odaklı girdi yoluyla öğrenme, anlam odaklı çıktı yoluyla öğrenme ve dil odaklı öğrenme ile birlikte, iyi dengelenmiş bir yabancı dil dersinin dört temel unsurundan biri olarak tanımlar ve akıcılık eğitimi ile alıştırmalarına toplam öğretim zamanının dörtte biri kadar yer verilmesi gerektiğini vurgular. Öğrencilerde akıcılığ vermeyen dil öğretim programlarında tutukluk öğrencilerin konuşurken hissettikleri bir sorun olarak varlığını devam ettirir. Hem ana dili hem de yabancı dil öğretimindeki önemine rağmen akıcı konuşmanın öğretimine çoğunlukla önem verilmez. Türkçenin yabancı dil olarak öğretiminde akıcı konuşma becerisinin geliştirilmesi için konuşmaya doğal ve normal olma niteliklerini kazandıran özellikler olan boğumlama, vurgu, tonlama, durak, ritim ve konuşma hızı ile Türkçenin parçalı ve parçalarüstü unsurlarını başlangıçtan itibaren kullanabilmeyi öğretmek gerekir.

Akıcı konuşma hem ana dilinde hem de ikinci dil veya yabancı dil öğretiminde iletişimde önemli bir yeterlilik seviyesi olarak tanımlanır ve içeriği şu özelliklerden oluşur:

1. Yazılı ve/veya sözlü dili kolaylıkla üretebilme,

2. Kabul edilebilir fakat mükemmel olmayan bir tonlama, kelime bilgisi ve dilbilgisi ile konuşabilme,

3. Fikirleri etkin bir şekilde iletebilme,

4. Anlama güçlüğü yaratmadan veya iletişimin kesilmesine neden olmadan kesintisiz konuşabilme (Richards ve Schmidt, 2010, s.222-223)

Türkçenin yabancı dil olarak öğrenilmesinde akıcılık öğretimi ve uygulamalarına yer verilmezse, öğrenciler konuşma konusunda tutukluk yaşayacaklardır. Durum böyleyken, akıcılık öğretiminin en temel gerekçesi olan konuşmada tutukluk hali, dil öğretiminde öncelik verilen bir alan olmak yerine, öğrencilerin artan yeterlilik seviyesi ile birlikte doğal olarak kendiliğinden ortadan kalkması beklenen bir dil 
yetersizliği olarak görülürse, akıcılık eğitiminin ihmale uğrama olasılığ1 yüksektir. Oysa ki akıcılık, Türkçenin yabancı dil olarak öğretimindeki diğer unsurlar gibi öğretilmesi ve uygulaması yapılması gereken bir alandır. Bu alanda etkinliği bilinen tekniklerin kullanılması, eğitim için ayrılan zaman içinde öğrenciler açısından kazanımı yüksek deneyimlerin elde edilmesine yol açacaktır. Bu etkili tekniklerden biri 4/3/2'dir (Maurice, 1983).

\section{4/3/2 Akıcı Konuşma Tekniği}

Bu teknik orta ve ileri seviye öğrencilerinin hedef dilde daha akıcı olarak konuşma becerilerini arttırmak için tasarlanmıştır. Burada amaç öğrencilere aşina oldukları bir konuyu giderek azalan süreler içinde üç kere farklı öğrencilere anlattırmaktır. İlk konuşma süresi 4 dakikadır. İkinci anlatımda süre 3 dakikaya iner ve dinleyici değişir. Üçüncü anlatımda süre 2 dakikaya iner ve dinleyici tekrar değişir. Maurice (1983, 130) bu tekniğin altında yatan mantığın üç unsurdan oluştuğunu söyler. Bunlar, aynı konuyu üç kere anlatma, farklı dinleyiciler ve azalan sürelerdir.

Aynı konuyu üç kere anlatma: İnsanlar bir konu hakkında ilk defa konuştuklarında "eee" gibi dolgu sesler kullanarak duraksama yapabilirler ya da tamamen durup yeniden konuşmaya başlayabilirler. Bu olağan bir durumdur. Maurice (1983) bu tutukluğun insanlar bir konuyu çok defa anlattıklarında azalmaya başladığını söyler.

Farklı dinleyiciler: Aynı konuyu aynı kişiye birden çok kere anlatma yapılan etkinliği anlamsız, mekanik bir uygulama haline getireceği ve hem konuşmacı hem de dinleyici için sıkıcı bir zorunluluk haline geleceği için, Maurice, dinleyicilerin değiştirilmesinin konuşmacının aynı konuyu başka birine anlatırken anlama önem vermesine olanak sağlayacağını söyler.

Azalan süreler: Maurice'e (1983) göre ilk dört dakika öğrencinin dille boğuşarak konu hakkındaki düşüncelerini ifadelendirme çabası ile geçer. $\mathrm{Bu}$ süre içinde çok sayıda duraksama olağandır. Üç dakikalık ikinci 
anlatım, aynı konuyu ikinci kez anlattığı için konuya daha hâkim olan öğrencinin ne söyleyeceğini bildiği için, anlatımını daha planlı bir biçimde ve daha az duraksama ile yapabilmesine olanak verir. Konuşmada sorunlar hala var olsa da, öğrenci kendini bu aşamada daha rahat hisseder. İki dakikalık üçüncü aşamanın amacı, ilk sefere göre yarı yarıya azalan zamanda aynı konuyu anlatmak durumda olan öğrenciyi olabildiğince akıcı ve doğal bir şekilde konuşmaya zorlamaktır. Bu aşama, öğrenci aynı konuyu üçüncü defa anlatacağı için, ona konuşmanın ana noktalarını seçme ve onları duraksamadan rahatça ifade edebilme becerisi kazandırır.

\section{4/3/2 Akıcı Konuşma Tekniğini Uygulama}

Etkinlik her uygulama için yaklaşık 40 dakika sürer. Bu sürenin yaklaşık ilk 7-10 dakikalık kısmı sınıftaki öğrencileri üç kişilik A ve B gruplarına bölmekle ve ne yapacakları konusunda onları bilgilendirmekle geçer. $\mathrm{Bu}$ aşamada öğretmen öğrencileri A ve B olarak isimlendirip, gruplara ayırdıktan sonra bütün A'lara konuşmaları için bir konu verir. Ardından, bu etkinliğin amacının her öğrencinin kendi konusunu karşı gruptaki üç farklı dinleyiciye her seferinde azalan süreler içinde anlatma yoluyla yabancı dil olarak öğrendikleri Türkçedeki akıcılıklarını arttırmak olduğunu belirtir. Öğretmen açıklama bölümünün son kısmında, dinleyici değişimi yapılması gerektiğini belirttiği zamanlarda A’lardaki üç kişinin yerlerinde sabit kalması, B’lerdeki üç kişinin ise sağa doğru hareket ederek eşlerini değiştirmesi gerektiğini söyler. Öğrenciler başlangıçtaki bu sürenin geri kalanında konuşmalarını planlamaya yoğunlaşırlar.

$\mathrm{Bu}$ sürenin ardından, öğretmen A öğrencilerinden birini seçer ve o öğrenci dört dakikalık ilk konuşmasına başlar. Bu sırada sınıftaki diğer öğrenciler konuşan arkadaşlarını izler, öğretmen ise süre tutar ve sürenin sona ermesinin ardından öğrencilerin duyabileceği bir sesle, "Eşini değiştir" der. Değişim sırasında Álar oldukları yerde oturmaya devam eder. B'ler ise sağ taraflarındaki başka A'lara doğru hareket ederler ve dinleyiciler değiş̧ir. Etkinliğin ikinci aşamasında 4 dakikalık konuşmasını tamamlamış olan ilk A öğrencisi karşısındaki yeni B'ye konusunu üç dakikada anlatmaya başlar. Öğretmenin ikinci eş 
değiştirme talimatının ardından, ilk A öğrencisi karşısındaki yeni B öğrencisine iki dakikalık süre içinde konusunu üçüncü defa anlatır. A'ların sabit kalıp, B’lerden 3 öğrencinin sağa doğru hareketiyle ilk A öğrencisi bireysel olarak 3 anlatımı gerçekleştirir ve etkinliği tamamlar.

Bu etkinlikte A gruplarında yer alan üç öğrenci bir konuyu üç kere anlatarak o konu hakkında adam başı 9 dakika, toplamda ise 27 dakika konuşur. Bu da konuşma eğitimi açısından kayda değer uzunlukta bir zamandır. Bu süreye ilave olarak, öğretmenin aralarda yaptığı eş değiştirme uyarıları ve öğrencilerin yeniden anlatma ve dinlemeye hazır hale gelmeleri için arada bırakılan 1 dakikalık zamanlarla birlikte A grubundaki öğrencilerin her birinin konusunu üç kere anlatması yaklaşık 11 dakikaya, toplamda ise yaklaşık 33 dakikaya denk gelir. İlk baştaki 7-10 dakikalık zamanla birlikte, bu da bir ders saati (40 dakika) içinde A grubundan 3 öğrencinin anlatım yapması için yeterli zaman demektir. Bu etkinlik Türkçenin yabancı dil olarak öğretiminde verimliliğin arttırılması için 18-24 kişi ile sınırlandırılan küçük sınıflarda haftada 2 saat uygulandığında, her hafta 6 öğrencinin anlatımıyla 18 kişilik sınıflarda 3 hafta, 24 kişilik sınıflarda ise 4 hafta süren bir etkinliğe dönüşür.

\section{Uygulamada Etkinliklerinde Kullanılan Konular}

Akıcılık etkinlikleri hedef dilin hızlı kullanımını gerektirdiği için, kullanılacak kelime ve dil bilgisi yapılarının öğrenciler tarafından bilinmesi önemlidir. Gerekli kelime ve dil bilgisine sahip olan öğrenciler, ifade edecekleri fikirler ve bunları nasıl aktaracakları üzerine yoğunlaşırlar. 4/3/2 tekniğinin etkin bir şekilde uygulanması için en çok gerekli unsurlardan biri de bu etkinliğin sınıf içi uygulamalarda kullanılırken içeriğinin ne olacağının bilinmesidir. Alanyazında 4/3/2 etkinliklerinde kullanılacak konuları ayrıntılı olarak tanımlayan iki çalışmadan bu aşamada bahsetmek yararlı olacaktır. Her iki çalışmanın ortak özelliği öğrencilere içeriğini kolayca dolduracakları varsayılan konuların bir liste halinde verilmesi ve bunları kendi konuşma önceliklerine göre sinıflandırmalarının istenmesidir. Bu listeler fikir vermek amaçlı olup öğretmenlerin kendi deneyimlerinin de konu belirleme sürecinde önemli olduğunu belirtmekte yarar vardır. 
Sayıca daha fazla konu içerdiği için burada ilk olarak verilen çalışmada Arab (2016) öğrencilere 24 konu vermiş ve bunları konuşma tercihlerine göre sıralamasını istemiştir. Öğrencilerin tercihleri Tablo 1 'de verilmiştir.

\section{Tablo 1. Konular ve öğrenci tercihleri}

\begin{tabular}{ll}
\hline Öğrencilerin Konu Tercihleri & $\%$ \\
\hline 1. Yolculuk yaptığınız ve çok beğendiniz bir yer hakkında konuşun & 97.29 \\
2. Üniversitedeki ilk gününüz hakkında konuşun & 86.48 \\
3. Sizi mutlu eden, üzen, geren, korkutan bir şeyi anlatın & 83.78 \\
4. Hayatınızla ilgili hayallerinizden bahsedin & 78.37 \\
5. En sevdiğiniz/En az sevdiğiniz yemeği anlatın & 59.45 \\
6. Bir arkadaşlığın sona ermesi & 51.35 \\
7. Gelecek ile ilgili planınıı anlatın ve gelecek için plan yapın & 51.35 \\
8. En iyi arkadaşlarınızdan birini tanıtın & 48.64 \\
9. Size gerçekten ilham veren biri veya herhangi bir şey var mı? & 43.24 \\
10. Gözlerinizden yaş gelene kadar sizi güldüren bir deneyim & 40.54 \\
11. İdeal öğretmeninizi anlatın & 40.54 \\
12. Tehlikeli bir deneyim & 37.83 \\
13. Ailenizi anlatın & 35.13 \\
14. Seyrettiğiniz en unutulmaz film hakkında konuşun. & 29.72 \\
15. İlginizi çeken bir seyahat etme yönteminden bahsedin (bisiklet, tren, uçak, balon) & 29.72 \\
16. Bir aile geleneğinizi anlatın & 27.02 \\
17. Sevdiğiniz veya nefret ettiğiniz bir müzik tarzını veya moda trendini anlatın & 27.02 \\
18. Hayatınızın hangi döneminde kendinizi çok özgür hissettiniz? & 21.62 \\
19. Bir kahramanlık öyküsü & 18.91 \\
20. Aldığınız önemli bir dersten bahsedin & 18.91 \\
21. Kutladığınız en son kutsal günden bahsedin & 18.91 \\
22. Sağlıklı bir yaşam tarzını nasıl sürdürdüğünüzü anlatın & 16.21 \\
23. Kendinizi tanıtın & 10.81 \\
24. Kendinizi bugün on yıl öncesine göre hangi açıdan farklı hissediyorsunuz? & 5.40 \\
\hline
\end{tabular}

İkinci çalışmada (Yang, 2014) öğrencilere 16 konu verilmiş ve bunlar hakkında tercihlerde bulunmaları istenmiştir. Bu sayede konular ve cinsiyetlere göre öğrenci tercihleri belirlenmiştir. Tablo 2 konulara ve öğrencilerin cinsiyetlerine göre konu tercih sıralarını vermektedir.

$\mathrm{Bu}$ iki çalışmada toplamda 40 konu verilmiştir. Bu konulardan birkaçında benzerlik olduğu da hemen fark edilecektir. Bu bölümde amaç bu tekniği hemen uygulamak isteyen öğretmenlere içerik oluşturma aşamasında konu bulmaları için yeterli bir temel oluşturmaktır. Dolayısıyla, arzu eden öğretmenler bu konuları temel alarak uygulamaya hemen başlayabilir, arzu edenler ise bunlardan yola çıarak öğrencilerine uygun konular bulabilirler. 
Tablo 2. Konulara ve cinsiyete göre öğrenci tercihleri

\begin{tabular}{lcc}
\hline Öğrencilerin Konu Tercihleri & Erkek \% & $\mathrm{K}_{1 z} \%$ \\
\hline 1. Kendinizi tanııı & 85.10 & 81.13 \\
2. Ailenizi tanıtın ve anlatın & 80.46 & 78.81 \\
3. Okul hayatınızı sınıf arkadaşlarınızla paylaşın & 79.47 & 85.43 \\
4. Şehrinizdeki hava durumu & 69.87 & 67.22 \\
5. Ulaşımın gelişimi & 64.24 & 61.26 \\
6. Spor ve rekabet & 91.72 & 37.42 \\
7. Eğlence ve hobiler & 87.09 & 83.77 \\
8. Alışveriş deneyimlerinizden bahsedin & 41.72 & 93.38 \\
9. İş nasıl bulunur & 77.15 & 79.80 \\
10. Bir adres sorun veya yol tarif edin & 66.23 & 59.27 \\
11. Günlük yiyecekler hakkında konuşun & 76.82 & 82.12 \\
12. Nasıl sağlıklı kalacağınızı araştırın & 73.51 & 80.13 \\
13. Hayatınızla ilgili hayallerinizi anlatın & 87.09 & 85.76 \\
14. Bir yere yaptığınız yolculuğu anlatın & 83.11 & 90.73 \\
15.Gelecek ile ilgili planınızı anlatın veya gelecek için plan yapın & 89.40 & 87.75 \\
16. En iyi arkadaşlarınızdan birini tanıtın & 80.46 & 76.16 \\
\hline
\end{tabular}

\section{4/3/2 Akıcı Konuşmayı Değerlendirme}

Değerlendirme için öğrencilerin 4 ve 2 dakikalık konuşmaları kaydedilmeli ve bunlar arasındaki farklılıkları bulmak amacıyla dört ölçüt dikkate alınmalıdır (Nation, 2009). Bunlardan ilki konuşma hızındaki artıştır. Hız artışı öğrencinin bir dakikada kullandığı kelime sayısı ile hesaplanır. Kaydedilen her metindeki toplam kelime sayısının dakika sayısına bölünmesiyle elde edilen bu değerler, iki konuşma arasındaki konuşma hızı artışını verecektir. İkinci ölçüt yine bu iki konuşma arasında öğrencilerin her 100 kelimede yaptıkları duraksamalar ve tutuklukların sayılarını karşılaştırmaktır. Üçüncü ölçüt dil bilgisi yanlışlarının sayılarının karşılaştırılmasıdır. Dördüncü ölçüt dört dakikalık konuşma ile kıyaslama yapıldığında iki dakikalık konuşma içinde iki ya da üç bileşik cümle olmasıdır. Nation (2009, s.135) iki konuşma arasında cümle yapısı farklılığı için şu örnekleri verir: Dört dakikalık öğrenci konuşmasında “Biz Paraparaumu'ya gittik. Paraparaumu Wellington'ın dışındadır" olarak iki basit cümle ile ifade edilen fikir, iki dakikalık konuşma sırasında "Biz Wellington'ın dişında olan Paraparaumu'ya gittik." olarak bir bileşik cümle haline gelmiştir.

Bu ölçütlerden de anlaşılacağı gibi 4/3/2 tekniğinde 4 ve 2 dakikalık öğrenci konuşmalarının kıyaslanması ile konuşma hızındaki artış, duraksamaların azalması, dil bilgisel doğruluğun artması ve karmaşık 
cümlelerin kullanılmasıyla öğrencilerde ne denli ilerleme olduğu ölçülür. Yukarıda verilen değerlendirme ölçütleri ve süreci hakkındaki bilgilendirmeden sonra, 4/3/2 etkinliğinin ölçülmesi ile ilgili iki çalışmadan bahsetmek uygulamanın nasıl yapıldığını ve tekniğin etkinliğini göstermek açısından yararlı olacaktır. Bunların ilkinde Nation (1989) 6 ileri seviye yetişkin öğrenciden başlarına gelen ilginç bir olayı anlatmalarını istemiş, konuşmalarını kaydetmiş ve metinleştirmiştir. Yaptığı veri analizinde kelime sayısındaki artma ile kendini gösteren hız artışı, daha az yapılan dil bilgisel hataların gösterdiği dil bilgisel doğruluk artışı ve aynı bilgiyi daha kısa bir zamana sıkıştırma becerisi ile ortaya çıkan içerik gelişmesi olduğunu tespit etmiştir.

İkinci çalışmada Arevart and Nation (1991) 20 orta düzey öğrenci ile benzer bir çalışma gerçekleştirmiş ve öğrencilerden istedikleri konularda konuşma yapmalarını istemiştir. Yapılan değerlendirmede akıcılık, dakikada kullanılan kelime sayısı ve tutukluk sayıları ile ölçülmüş ve bazı öğrencilerde konuşma hızı açısından \%20'ye varan artışlar tespit edilmiştir.

\section{4/3/2' nin farklı versiyonları}

İki önemli gerekçeden dolayı bu etkili tekniğin farklı versiyonları ortaya çıkmıştır. Bunlardan ilki öğrencilerin dil seviyelerinin yetersizliğidir. İkinci neden ise ders saati sürelerinin azlığıdır. Bunlardan ilki olan dil yetersizliği ile ilgili olarak Arab (2016) öğrencileri orta seviyede olmalarına rağmen dile iyice hâkim olamadıklarından 4/3/2 dakikanın konuşabilecekleri süreden uzun olduğunu tespit etmiş ve tekniği öğrencilerinin gerçek seviyesine uygun olması amacıyla 3/2/1 olarak uyarlamıştır. Aynı şekilde, Tezel (2017) düşük seviyelerde bu etkinliği 4/3/2 yerine 3/2/1 $1 / 2$ dakika yapmanın daha kolay olabileceğini belirtir.

İkinci versiyonun ortaya çıkma nedeni ders saati süresi ile ilgili sorunlardır. Molina ve Briesmaster (2017) haftalık 90 dakika olan ders saati süresinin az olması, öğrencilerin eşleştirilmeleri, konuların dağıtımı ve etkinliğin başlatılması aşamalarında yaşanan sınıf yönetimiyle ilgili sorunlar nedeniyle bu etkinliği 3/2/1 olarak haftada bir kere yaptıklarını söyler 


\section{Sonuç}

Konuşmada akıcılık eğitim yoluyla kazandırılan bir beceridir (Arevart ve Nation, 1991). 4/3/2 tekniği uzun konuşmalarla aynı mesajın tekrar yoluyla verilmesini sağlayarak akıcılığın gelişmesine olanak sağlar. Bu tekniğin kullanımı sayesinde öğrenciler akıcılık konusunda elde ettikleri ve bireysel dil yeterliklerinin bir parçası haline gelen birikim ile hızlı konuşmalarına ve doğruluğu yüksek karmaşık cümleler oluşturmalarına olanak sağlayacak bir uygulama aracına kavuşmuş olacaklardır.

Burada bahsedilen çalışmaların sonuçlarından da görüldüğü gibi, 4/3/2 tekniği öğrencilerin konuşmada akıcılıklarını geliştirmelerine aynı mesajın azalan süreler içinde tekrarının yapılması yoluyla olanak sağlamasıyla kayda değer yardımlarda bulunan etkin bir tekniktir. Bu teknik araştırmalarla desteklenen başarılı sonuçları ile Türkçenin yabancı dil olarak öğretiminde konuşma becerisinde akıcılı̆̆ın geliştirilmesi için öğretmenlere ve araştırmacılara etkili bir araç sunmaktadır. 
EXTENDED ABSTRACT

\title{
4/3/2: An Effective Technique to Develop Fluency in Speaking in Teaching Turkish as a Foreign Language
}

\author{
Kadir Vefa Tezel \\ Bolu Abant Izzet Baysal University
}

In teaching Turkish as a foreign language, one of the most common problems learners experience is the hesitations they encounter while expressing their feelings and thoughts verbally. Although learners possess the language proficiency to express whatever crosses their minds comfortably in their native language, they frequently experience difficulties choosing the right words and grammatical structures and transforming their thoughts into utterances when they use Turkish. These difficulties manifest themselves as pauses and hesitations that occur when learners speak. This situation, which is very common but certainly not desired, is caused by the lack of fluency in speaking.

\section{Fluency in Speaking}

Nation and Newton (2009) define fluency as one of the four key elements of a well-balanced foreign language course, with learning through meaning-focused input, learning through meaning-focused output, and language-focused learning, and add that a quarter of the total teaching time should be devoted to teaching and practicing fluency. Fluency in speaking is acquired through training (Arevart \& Nation, 1991). If fluency education and practices are not included in teaching Turkish as a foreign language, learners will continue to experience problems in speaking. The use of techniques that are known to be effective in this area will serve to eliminate this problem. One of these effective techniques is $4 / 3 / 2$ (Maurice, 1983). 


\section{4/3/2 Fluent Speaking Technique}

This technique is designed to increase the ability of intermediate and advanced students to speak more fluently in the target language. The goal is to have learners talk about a familiar topic to different learners three times in gradually decreasing times. The length of the first talk is 4 minutes. In the second talk, the time is reduced to 3 minutes, and the audience changes. For the third talk, the time is reduced to 2 minutes, and the listener changes once again. Maurice $(1983,130)$ states that the rationale underlying this technique consists of three elements: talking about the same topic three times, different audiences, and decreasing time.

Talking about the same topic three times: When people talk about a topic for the first time, they may pause using pause fillers like "um" or stop completely to organize their thoughts and plan what they will say. This initial arduousness is quite common. Maurice (1983) states that the initial hesitations start to decrease when people talk about a topic many times.

Different audiences: As telling the same topic multiple times to the same person would make an activity meaningless, mechanical, and become boring for both the speaker and the listener, changing audiences motivates speakers to exert genuine effort while talking about the same topic with a new person.

Decreasing time: According to Maurice (1983), the first four minutes are spent by the learner struggling with language and trying to express his thoughts on the subject. Numerous pauses are normal during that time. The second three-minute period allows learners to talk about the same topic in a more planned way and with fewer pauses. The final twominute phase forces learners to talk about the same topic in half the time compared with the first time. This final stage allows learners to choose the main points and express them comfortably without hesitation. 


\section{Using $4 / 3 / 2$ in the classroom}

The activity lasts approximately 40 minutes. The teacher spends the first 7-10 minutes dividing the learners into groups of three as $\mathrm{A}$ and $\mathrm{B}$ and informing them about what they will have to do. The teacher gives all A's a topic to talk about. Then, he tells the learners that the goal is to increase their speaking fluency by talking to three different listeners about that topic in decreasing time limits. A's remain in their places and B's move to the right to become new listeners for the A's. Learners concentrate on planning their speech for the remainder of this initial period.

Afterwards, the teacher chooses one of the A's to start his first fourminute speech. All other classmates follow the talk. The teacher says, "Change your partner" when the time ends. After the audience change, the speaker begins to talk about his subject for the second time to a new $B$ in three minutes. Following the teacher's second instruction to change partners, the A tells the last B about his topic for the third time in two minutes. This way, the first A completes the activity after talking about the topic for 9 minutes. There are two one-minute intervals in between the three performances to allow switching listeners and give time for the speaker to become ready for the next performance.

\section{Topics Used in Practicing 4/3/2}

The more familiar learners become with the ideas they are going to express, the more comfortable they will be in elaborating the content of their talk. Therefore, they should be given topics that they can talk about easily. Examples of topics learners feel comfortable talking about are: Tell your friend about your favorite/least favorite food, Introduce one of your best friends, Talk about your family, Talk about the most memorable movie you have watched, Introduce yourself, Talk about your future plans or plan for the future, and Introduce one of your best friends. 


\section{Evaluating Student Performance}

For the evaluation of learners' performance, their 4- and 2-minute speeches should be recorded, and four criteria should be taken into consideration to identify the differences (Nation, 2009). The first is the increase in speech rate. It is measured by dividing the total number of words in each recording by the number of minutes. The second is comparing the number of pauses per 100 words between the two speeches. The third is the comparison of the number of grammatical errors. The fourth is the number of complex sentences in the two-minute speech compared with the four-minute speech.

The 4/3/2 technique allows learners to develop their fluency in speaking by having them retell the same message in decreasing time limits. It is an effective technique that improves fluency in speaking.

\section{Kaynakça / References}

Arab, O. (2016). The effect of the $4 / 3 / 2$ technique on students' speaking fluency. Revue EXPRESSIONS, 2, 1-11.

Arevart, S. and Nation, P. (1991). Fluency improvement in a second language. RELC Journal, 22(1). 84-94. DOI: $10.1177 / 003368829102200106$

Molina, M. and Briesmaster, M. (2017). The use of the $3 / 2 / 1$ technique to foster students' speaking fluency. i.e.: inquiry in education, 9(2), 1-13.

Maden, S. ve İşcan, A . (2011). Yabancı dil olarak Türkçe öğretimi amaç ve sorunlar (Hindistan örneği). Karadeniz Sosyal Bilimler Dergisi, 3(5),2337.

Maurice, K. (1983). The fluency workshop. TESOL Newsletter,1,130.

Nation, P. (1989). Improving speaking fluency. System, 17( 3), 377-384.

Nation, P. (2009). Reading faster. International Journal of English Studies, 9(2). 131-144.

Nation, I. S. P. and Newton, J. (2009). Teaching ESL/EFL listening and speaking. New York, NY: Routledge.

Richards, J. C. and Schmidt, R. W. (1992). Longman dictionary of language teaching and applied linguistics. (4. Ed). London, England: Longman.

Tezel, K. V. (2017). Bir yabancı dili öğrenmek için neleri bilmeniz gerekir? https://www.turkceogretimi.com/kitap-cd-ve-siteler/bir-yabanc\%C4\%B1- 
dili$\%$ C3\%B6\%C4\%9Frenmek-i\%C3\%A7in-neleri-bilmeniz-gerekir Adresinden 18.01.2021 arihinde erişilmiştir.

Yang, Y. I. J. (2014). The implementation of speaking fluency in communicative language teaching: An observation of adopting the 4/3/2 activity in high schools in China. International Journal of English Language Education, 2(1), 193-214.

\section{Kaynakça Bilgisi / Citation Information}

Tezel, K. V. (2021). 4/3/2: Yabanc1 dil olarak Türkçe öğretiminde konuşmada akıcılığı geliştirmek için etkili bir teknik. OPUSUluslararası Toplum Araştırmaları Dergisi, 18(41), 3778-3793. DOI: 10.26466/opus.885529. 